(c) American Dairy Science Association, 2004.

\title{
Changes in Milk Fat in Response to Dietary Supplementation with Calcium Salts of Trans-18:1 or Conjugated Linoleic Fatty Acids in Lactating Dairy Cows
}

\author{
L. S. Piperova, ${ }^{1}$ U. Moallem, ${ }^{1}$ B. B. Teter, ${ }^{2}$ J. Sampugna, ${ }^{2}$ M. P. Yurawecz, ${ }^{3}$ \\ K. M. Morehouse, ${ }^{3}$ D. Luchini, ${ }^{4}$ and R. A. Erdman ${ }^{1}$ \\ ${ }^{1}$ Animal and Avian Sciences Department, and \\ ${ }^{2}$ Department of Chemistry and Biochemistry, \\ University of Maryland, College Park 20742 \\ ${ }^{3}$ US Food and Drug Administration, \\ Center for Food Safety and Applied Nutrition, \\ College Park, MD 20742 \\ ${ }^{4}$ Bioproducts Inc., Fairlawn, OH 44333
}

\section{ABSTRACT}

Milk fat was investigated in lactating dairy cows fed diets supplemented with Ca salts of trans fatty acids (Ca-tFA) or Ca salts of conjugated linoleic acids (CaCLA). Forty-five Holstein cows (115 days in milk) were fed a control diet (51\% forage; dry matter basis) supplemented with $400 \mathrm{~g}$ of EnerG II (Ca salts of palm oil fatty acids) for 2 wk; subsequently, 5 groups of 9 cows each were assigned for $4 \mathrm{wk}$ to the control diet or diets containing $100 \mathrm{~g}$ of Ca-CLA or 100, 200, or $400 \mathrm{~g}$ of CatFA in a randomized block design. Treatments had no effect on dry matter intake, milk production, protein, lactose, or somatic cell count. Milk fat percentage was reduced from $3.39 \%$ in controls to $3.30,3.04$, and $2.98 \%$, respectively, by the Ca-tFA diets and to $2.54 \%$ by the Ca-CLA diet. Milk fat yield (1.24 kg/d in controls) was decreased by 60,130 , and $190 \mathrm{~g} / \mathrm{d}$ with increasing dose of Ca-tFA and by $290 \mathrm{~g} / \mathrm{d}$ with the Ca-CLA supplement. Consistent with increased endogenous synthesis of cis9-containing CLA from precursors provided by the CatFA diets, total CLA were similar in milk of cows fed Ca-CLA or Ca-tFA. Compared with controls, the CaCLA diet increased trans-10, cis-12-18:2 yield in milk, without altering levels of trans-18:1 isomers. In contrast, yields of most trans-18:1 isomers were elevated in milk of cows fed Ca-tFA diets, whereas yields of trans-10, cis-12-18:2 remained similar to control values. We conclude that milk fat depression can occur without an increase in trans-10, cis-12-18:2 in milk and that other components, perhaps the trans-10-18:1 isomer, may be involved.

(Key words: lactating cow, trans fatty acids, conjugated linoleic acids)

Received February 2, 2004.

Accepted June 23, 2004.

Corresponding author: R. A. Erdman; e-mail: erdman@umd.edu.
Abbreviation key: Ca-CLA = Ca salt of conjugated linoleic acids, Ca-tFA = Ca salt of trans-18:1 fatty acids, CLA = conjugated linoleic acids, FAME = fatty acid methyl ester, MFD = milk fat depression, PUFA = polyunsaturated fatty acids, SFA = saturated fatty acids, $\mathbf{t F A}=$ trans-18:1 fatty acids.

\section{INTRODUCTION}

Trans-18:1 fatty acids (tFA) and conjugated linoleic acids (CLA) produced during biohydrogenation of polyunsaturated fatty acids (PUFA) in the rumen are mixtures of positional isomers (Katz and Keeney, 1966; Griinari and Bauman, 1999), which subsequently are incorporated into milk fat of lactating cows (Parodi, 1977; Griinari and Bauman, 1999; Loor and Herbein, 2001; Piperova et al., 2002; Precht et al., 2002). Studies have demonstrated that levels of tFA (Kalscheur et al., 1997a; Griinari et al., 1998; Piperova et al., 2000) and CLA isomers (Piperova et al., 2000, 2002; Peterson et al., 2003) increase in milk fat of lactating cows fed a variety of diets associated with milk fat depression (MFD). Because of the active biohydrogenation process in the rumen, abomasal infusion has been the best approach to study effects of specific isomers on milk fat synthesis. Using abomasal infusion of trans-10, cis-1218:2, Baumgard et al. (2000) provided evidence that this is one isomer involved in MFD. The role of tFA in MFD has been examined using partially hydrogenated vegetable oils, and we have previously shown (Gaynor et al., 1994; Romo et al., 1996) that abomasal infusion of partially hydrogenated vegetable oils in lactating cows results in elevated amounts of tFA in milk and a 14 to $25 \%$ reduction in milk fat percentage.

Griinari et al. (1998) and Griinari and Bauman (1999) reported a specific association between dietary-induced MFD and increased trans-10-18:1 in milk of lactating cows and found a linear relationship between trans-10- 
18:1 and trans-10, cis-12-18:2. Griinari and Bauman (1999) suggested that the trans-10-18:1 resulted from trans-10, cis-12-18:2 during rumen biohydrogenation, and recently Loor and Herbein (2001) provided direct evidence for this hypothesis. Subsequently, others have reported an increase in the concentrations of trans-10, cis-12-18:2 (Piperova et al., 2000; Peterson et al., 2003) and trans-10-18:1 (Newbold et al., 1998; Piperova et al., 2000; Piperova et al., 2002; Peterson et al., 2003) in milk of lactating cows fed MFD diets. Because of the concomitant increase in trans-10, cis-12-18:2 with trans-18:1 isomers, and especially trans-10-18:1, it has been difficult to demonstrate an independent effect of tFA during dietary-induced MFD.

Feeding diets supplemented with Ca salts of fatty acids is a practical way to bypass rumen biohydrogenation. Studies have already shown that diets supplemented with Ca salts of CLA (Ca-CLA) effectively reduce milk fat percentage and yield in lactating cows (Giesy et al., 2002; Perfield II et al., 2002; Bernal-Santos et al., 2003). Dietary Ca salts of tFA (Ca-tFA) supplementation could potentially increase the postruminal availability of trans-18:1 fatty acids and provide an alternative to abomasal infusion to test the potential effects of trans-18:1 fatty acids on milk fat synthesis. Hence, this study was undertaken to examine the effects of a dietary Ca-tFA or Ca-CLA supplementation on milk fat content and fatty acid isomer profile in lactating dairy cows.

\section{MATERIALS AND METHODS}

\section{Animals, Treatments, and Sampling}

The experiment was conducted according to a protocol approved by the University of Maryland Institutional Animal Care and Use Committee. The Ca-fatty acid supplements used in this study were provided by Bioproducts Inc., (Fairlawn, OH). Forty-five lactating Holstein dairy cows (15 primiparous and 30 multiparous) at approximately 115 DIM were fed a control diet containing $51 \%$ forage and $49 \%$ concentrate (DM basis), supplemented with $400 \mathrm{~g}$ of EnerG II (Ca salts of palm oil fatty acids) during a 2 -wk adjustment period. After the adjustment period, cows ( $\mathrm{n}=9$ per group) were assigned to 1 of 5 treatments: control or 4 diets supplemented with either $100 \mathrm{~g}$ of Ca-CLA or with 100, 200, or $400 \mathrm{~g}$ of $\mathrm{Ca}-\mathrm{tFA}$ in a randomized block design. In the treatment diets, the Ca-CLA and Ca-tFA supplements substituted for equal parts of EnerG II in the control diet. The amount of Ca-CLA fed in this study was based on results obtained by others using dietary Ca-CLA supplementation to reduce milk fat in lactating cows (Giesy et al., 2002; Perfield II et al., 2002). The $100 \mathrm{~g}$ of Ca-CLA supplement provided $13 \mathrm{~g} / \mathrm{d}$ of total CLA,
Table 1. Fatty acid composition of Ca supplements. ${ }^{1}$

\begin{tabular}{|c|c|c|c|}
\hline Fatty acid & EnerG II & Ca-tFA & Ca-CLA \\
\hline & \multicolumn{3}{|c|}{$\mathrm{g} / 100 \mathrm{~g}$ of fatty acid } \\
\hline $14: 0$ & & & 0.61 \\
\hline $16: 0$ & 45.7 & 12.5 & 29.2 \\
\hline $16: 1$ & & & 0.2 \\
\hline $18: 0$ & 4.9 & 22.1 & 3.5 \\
\hline 18:1 trans & & 53.3 & \\
\hline $18: 1 \mathrm{cis}$ & 38.5 & 8.3 & 29.5 \\
\hline $18: 2 \mathrm{n}-6$ & 9.8 & 1.8 & 17.6 \\
\hline $18: 2 \mathrm{i}^{2}$ & & 1.6 & \\
\hline CLA & & & 18.5 \\
\hline Other & 1.1 & 0.3 & 0.9 \\
\hline
\end{tabular}

${ }^{1}$ Control cows received a dietary supplement of $\mathrm{Ca}$ salts of palm oil fatty acids (EnerG II), providing $60 \mathrm{~g} / \mathrm{d}$ of fatty acids $/ 100 \mathrm{~g}$ of supplement. The Ca-tFA (Ca salt of trans fatty acids) and Ca-CLA (Ca salt of conjugated linoleic acids) treatments provided 60 and 70 $\mathrm{g} / \mathrm{d}$ of fatty acids/100 $\mathrm{g}$ of supplement, respectively.

${ }^{2} 18: 2 \mathrm{i}=$ nonconjugated dienes with 1 or 2 trans double bonds.

containing $4.65 \mathrm{~g}$ of trans-10, cis-12-18:2 isomer, which is within the range used by others to achieve MFD. The Ca-tFA supplement provided 32,64 , and $128 \mathrm{~g} / \mathrm{d}$ of tFA with the 100, 200, and $400 \mathrm{~g}$ of Ca-tFA, respectively. We used data from previous experiments, especially Kalscheur et al. (1997a) and Piperova et al. (2002), to estimate the expected increase in the amounts of $\mathrm{tFA}$ $(\sim 30 \mathrm{~g} / \mathrm{d})$ and trans $-10-18: 1(\sim 10 \mathrm{~g} / \mathrm{d})$ in milk fat of lactating cows exhibiting MFD. Assuming 50\% biohydrogenation (Wu et al., 1991; Wu and Palmquist, 1991) of the Ca-tFA in the rumen, we calculated that the 200-g dose of Ca-tFA should provide the levels required. The fatty acid compositions of the supplements are shown in Table 1, and the distribution pattern of the tFA and CLA isomers in the Ca supplements is given in Table 2 .

The ingredient and chemical composition of the basal diet is shown in Table 3. Forage and concentrate DM was measured weekly, and the TMR was adjusted accordingly to maintain a constant forage-to-concentrate ratio on a DM basis during the experiment. Cows were housed in a free-stall barn and were fed individually.

Table 2. Isomer profile of the Ca-tFA (Ca salt of trans fatty acids) and Ca-CLA (Ca salt of conjugated linoleic acids) supplements.

\begin{tabular}{lllr}
\hline \multicolumn{2}{c}{$\begin{array}{c}\text { trans-18:1 isomers } \\
\left(\% \text { of total tFA }{ }^{1}\right)\end{array}$} & \multicolumn{2}{c}{$\begin{array}{c}\text { CLA }^{2} \text { isomers } \\
(\% \text { of total CLA })\end{array}$} \\
\hline trans-6-8 & 10.20 & trans -11, cis -13 & 0.1 \\
trans -9 & 16.20 & cis -11, trans -13 & 11.50 \\
trans -10 & 28.01 & trans -10, cis -12 & 35.83 \\
trans -11 & 20.01 & cis-9, trans -11 & 35.08 \\
trans -12 & 11.50 & trans -8, cis -10 & 8.46 \\
trans $-13+14$ & 10.50 & trans/trans CLA & 4.73 \\
trans -15 & 1.82 & cis/cis CLA & 4.30 \\
trans -16 & 0.92 & & \\
\hline
\end{tabular}

${ }^{1} \mathrm{tFA}=$ Trans-18:1 fatty acids.

${ }^{2} \mathrm{CLA}=$ Conjugated linoleic acids. 
Table 3. Ingredients and chemical composition of basal diet.

\begin{tabular}{|c|c|}
\hline \multicolumn{2}{|l|}{ Ingredient } \\
\hline & $(\%$ of $\mathrm{DM})$ \\
\hline Corn grain, ground & 1.7 \\
\hline HMSC $^{1}$ & 20.0 \\
\hline Soybean meal & 14.3 \\
\hline Soybean roasted & 3.8 \\
\hline Dried citrus pulp & 5.3 \\
\hline Corn silage & 42.5 \\
\hline Alfalfa hay & 9.2 \\
\hline Dicalcium phosphate & 0.5 \\
\hline $\mathrm{KCl}$ & 0.5 \\
\hline $\mathrm{NaCl}$ & 0.4 \\
\hline $\mathrm{MgO}$ & 0.2 \\
\hline Potassium-magnesium sulfate & 0.6 \\
\hline Trace minerals and vitamins ${ }^{2}$ & 1.4 \\
\hline EnerG II ${ }^{3}$ & 1.8 \\
\hline \multicolumn{2}{|l|}{ Estimated chemical composition } \\
\hline $\mathrm{DM}, \%$ & 48.6 \\
\hline $\mathrm{CP}, \%$ & 17.6 \\
\hline RUP, \% & 6.8 \\
\hline $\mathrm{ADF}, \%$ & 17.7 \\
\hline NDF, $\%$ & 30.2 \\
\hline Net energy for lactation, Mcal $/ \mathrm{kg}$ & 1.82 \\
\hline $\mathrm{Ca}, \%$ & 0.75 \\
\hline $\mathrm{P}, \%$ & 0.37 \\
\hline $\mathrm{Na}, \%$ & 0.31 \\
\hline $\mathrm{Mg}, \%$ & 0.30 \\
\hline $\mathrm{S}, \%$ & 0.15 \\
\hline $\mathrm{K}, \%$ & 1.32 \\
\hline $\mathrm{Cl}, \%$ & 0.41 \\
\hline
\end{tabular}

${ }^{1}$ HMSC $=$ High moisture shelled corn.

${ }^{2}$ Combined $549 \mathrm{~g} / \mathrm{kg}$ of calcium carbonate and $451 \mathrm{~g} / \mathrm{kg}$ of trace mineral and vitamin mix. Trace mineral and vitamin mix combined (per kg mix) $24 \mathrm{~g} \mathrm{Mn}, 24 \mathrm{~g} \mathrm{Zn}, 6.5 \mathrm{~g} \mathrm{Cu}, 0.29 \mathrm{~g} \mathrm{I}, 0.048 \mathrm{~g} \mathrm{Co}, 0.144$ $\mathrm{g}$ Se, $0.95 \mathrm{~g}$ retinyl acetate, $0.018 \mathrm{~g}$ cholecalciferol, and $12.67 \mathrm{~g}$ DLtocopheryl acetate.

${ }^{3} \mathrm{Ca}$ salts of palm oil fatty acids (Bioproducts Inc., Fairlawn, OH).

Diets were fed as TMR once daily at $0800 \mathrm{~h}$, refusals were measured, and DMI was calculated daily. Cows were milked, and milk production was recorded at 0600 and $1600 \mathrm{~h}$ every day. Milk samples were collected during the last $3 \mathrm{~d}$ ( 6 consecutive milkings) of the adjustment and the treatment periods and composited. Milk fat, protein, lactose, and somatic cell count were analyzed by infrared analyses (AOAC, 1990; Foss Milkoscan; Foss Food Technology Corp., Eden Prairie, MN).

\section{Fatty Acid Composition}

Milk fat was extracted, and fatty acid methyl esters (FAME) were prepared by a mild transesterification with $0.4 \mathrm{~mol} / \mathrm{L} \mathrm{H}_{2} \mathrm{SO}_{4}$ in methanol, as previously described (Piperova et al., 2002). The composition of FAME was determined by GLC analysis using a $60 \mathrm{~m}$ $\times 0.25 \mathrm{~mm}$ CP-Sil 88 fused-silica capillary column (Chrompack, Middelburg, The Netherlands) in a HP5890 II GLC system. Total tFA methyl ester was obtained after separation of FAME on $\mathrm{Ag}^{+}-\mathrm{TLC}$ (Sampugna et al., 1982), using FAME of 14:0, cis-9-18:1 and trans-9-18:1 standards to locate the fractions of interest. Trans fatty acid isomers were separated on a $100 \mathrm{~m}$ $\times 0.25$-mm fused-silica capillary column (SP-2560, Supelco Inc., Bellefonte, PA) in a GLC system and under conditions previously described (Piperova et al., 2000). Individual 18:1 isomers were identified with the help of authentic cis- and trans-18:1 fatty acids, as described by Piperova et al. (2000).

Milk FAME were analyzed for CLA content and isomer distribution using a combination of GLC and $\mathrm{Ag}^{+}$ HPLC as previously described (Piperova et al., 2000). Aliquots $(60 \mu \mathrm{L})$ of each sample were diluted in 940 $\mu \mathrm{L}$ hexane and were used in HPLC analysis; a typical injection volume was $50 \mu \mathrm{L}$, containing 100 to $112 \mu \mathrm{g}$ of FAME. Details on the identification and quantification of the CLA isomers by HPLC analysis have been reported elsewhere (Eulitz et al., 1999; Sehat et al., 1998).

\section{Statistical Analysis}

Data were analyzed using the Mixed Procedure of SAS (1998). The model included treatment as fixed effect and observations at the end of the adjustment period as covariate. The random portion of the model included the block effect. Tests of significance included linear and quadratic contrasts to test the effect of CatFA dose $(0,100,200$, and $400 \mathrm{~g})$, and contrasts for CLA vs. control and CLA vs. tFA treatments. Probability of $P \leq 0.05$ was considered to be statistically significant.

\section{RESULTS}

Gas-liquid chromatography analysis of the Ca-tFA FAME revealed that trans-18:1 positional isomers with a double bond from delta- 6 to delta- 16 were present in the supplement, with trans-10 being the major isomer (Table 2). However, except for the trans-15 and trans16-18:1, which were minor components, a considerable proportion of trans-11-18:1 was also present (20\%), as well as from 10.2 to $11.5 \%$ of each of the remaining trans-18:1 components. In contrast, there was no evidence for trans-monoenes in the Ca-CLA supplement. The Ca-CLA contained nearly equal amounts of $c i s-9$, trans-11-18:2 (4.56 g) and trans-10, cis-12-18:2 (4.65 g), as well as several other isomers. However, there was no evidence for trans-7, cis-9-18:2 (Table 2). The CatFA supplement was also examined for CLA, but only trace amounts of uncharacterized trienes and trans, trans dienes were detected (data not shown).

Dietary DMI, milk production, and milk composition data are presented in Table 4. Feed intake and milk yield were unaffected by dietary treatments. Milk protein and lactose content and yield were similar among 
Table 4. Dry matter intake, milk production, and milk composition of cows fed diets supplemented with Ca salts of trans fatty acids (tFA) or conjugated linoleic acids (CLA). ${ }^{1}$

\begin{tabular}{|c|c|c|c|c|c|c|c|c|c|c|}
\hline \multirow[b]{3}{*}{ Item } & \multirow[b]{3}{*}{ Control } & \multirow{2}{*}{\multicolumn{3}{|c|}{ Ca-tFA }} & \multirow{3}{*}{$\frac{\mathrm{Ca}-\mathrm{CLA}}{100 \mathrm{~g}}$} & \multirow[b]{3}{*}{ SEM } & \multicolumn{4}{|c|}{ Contrast } \\
\hline & & & & & & & & & CLA vs. & CLA vs. \\
\hline & & $100 \mathrm{~g}$ & $200 \mathrm{~g}$ & $400 \mathrm{~g}$ & & & $\mathrm{~L}^{2}$ & $\mathrm{Q}^{2}$ & control & tFA \\
\hline DMI, kg/d & 23.5 & 25.1 & 23.9 & 23.0 & 23.5 & 0.59 & 0.17 & 0.09 & 0.92 & 0.45 \\
\hline Milk yield, kg/d & 37.8 & 35.9 & 36.2 & 36.4 & 35.2 & 1.36 & 0.67 & 0.61 & 0.33 & 0.24 \\
\hline Milk fat, \% & 3.39 & 3.30 & 3.04 & 2.98 & 2.54 & 0.06 & 0.03 & 0.76 & 0.01 & 0.01 \\
\hline Fat yield, kg/d & 1.24 & 1.18 & 1.11 & 1.05 & 0.95 & 0.03 & 0.02 & 0.81 & 0.01 & 0.01 \\
\hline Milk protein, \% & 3.05 & 2.89 & 2.97 & 3.08 & 3.03 & 0.02 & 0.23 & 0.08 & 0.77 & 0.55 \\
\hline Protein yield, kg/d & 1.09 & 1.04 & 1.08 & 1.08 & 1.14 & 0.19 & 0.90 & 0.69 & 0.37 & 0.13 \\
\hline Milk lactose, $\%$ & 4.88 & 4.84 & 4.86 & 4.92 & 4.83 & 0.03 & 0.28 & 0.31 & 0.46 & 0.35 \\
\hline $\mathrm{SCC}, \times 1000 / \mathrm{mL}$ & 415 & 233 & 341 & 322 & 245 & 85 & 0.97 & 0.43 & 0.66 & 0.54 \\
\hline
\end{tabular}

treatments. Compared with the control cows, milk fat percentage and yield were decreased 3,10 , and $12 \%(P$ $<0.03)$ and 5,11 , and $15 \%(P<0.02)$, respectively, in cows fed the Ca-tFA diets. Milk fat depression was greatest in cows fed the Ca-CLA diet, as milk fat percentage and yield were reduced by $25 \%(P<0.01)$ and by $23 \%(P<0.01)$, respectively, compared with the control.

Short- and medium-chain fatty acids were analyzed in a subset of milk samples (data not shown). Except for the butyric acid, milk yield of other fatty acids (6:0 to 12:0), synthesized in the mammary gland, tended to be lower in cows fed the Ca-tFA or Ca-CLA diets. Concentrations (g/100 g FAME) and yield (g/d) of individual fatty acids in milk fat are shown in Tables 5 and 6 , respectively. Compared with the control cows, yield of both total saturated and cis-monounsaturated fatty acids was reduced by $25 \%(P<0.05)$ and $26 \%(P<0.05)$, respectively, by Ca-CLA (Table 6 ). Increasing amounts of Ca-tFA also decreased $(P<0.01)$ total yield of saturated fatty acids (SFA) (Table 6). This was largely due to the reduction in milk fat yield as concentrations of SFA were lower $(P<0.02)$ for C16:0 but numerically increased for C18:0 (Table 5). With the highest dose of Ca-tFA, yields of monounsaturated and SFA were reduced by 14 and $16 \%$, respectively, again largely because of the overall reduction in milk fat yield. Secretion of PUFA was unchanged by the Ca-tFA diets, although it was numerically less, but not statistically different from the control, in milk of cows fed Ca-CLA.

Compared with the control, the concentration (Table 5 ) and yield (Table 6 ) of total CLA were greater in milk of cows fed the Ca-CLA $(P<0.05)$ and Ca-tFA $(P<0.02)$ diets. However, milk yield of CLA was not significantly different between the Ca-tFA and Ca-CLA treatments (Table 6). The CLA isomers in milk are presented in Table 7. Regardless of diet, cis-9, trans-11-18:2 was the predominant CLA isomer, varying from 68 to $76 \%$ of total CLA. Yields of cis-9, trans-11-18:2 $(P<0.03)$ and trans-7, cis-9-18:2 $(P<0.05)$ were increased in milk with Ca-tFA supplementation and were higher than in milk of cows fed the control and the Ca-CLA diets. Compared with the controls, yield of cis-9, trans-1118:2 was increased $(P<0.05)$ by the Ca-CLA supplementation, while trans-7, cis-9-18:2 was not different. As expected, the yield of trans-10, cis-12-18:2 $(P<0.01)$ was greatest in milk of cows fed the Ca-CLA diet, but the trans-8, cis-10-18:2 isomer was not found in measurable quantities in milk, even though it was present at $8.5 \%$ in the Ca-CLA supplement.

Total tFA percentage $(P<0.01)$ and yield $(P<0.03)$ were increased in milk of cows fed the Ca-tFA supplement (Tables 5 and 6). Except for the trans-15 and trans-16-18:1, which were minor components in the CatFA isomer mixture, milk yields of the other trans-18:1 isomers (Table 8) were elevated with dietary addition of Ca-tFA. Trans-11-18:1 was the primary milk tFA isomer with each treatment and accounted for 24 to $29 \%$ of the total trans-18:1 isomers. Distribution of trans-18:1 isomers in milk of the cows fed Ca-CLA was similar to that observed in the control cows.

\section{DISCUSSION}

The Ca-tFA supplement used in this study was effective in decreasing milk fat yield without altering milk production. However, MFD in cows fed Ca-tFA was less pronounced compared with cows fed the Ca-CLA supplement. As expected, trans-10, cis-12-18:2, identified as the isomer responsible for MFD (Baumgard et al., 2000), was increased in milk fat of cows fed the CaCLA supplement. In contrast, the levels of this CLA isomer in milk of cows fed Ca-tFA diets did not increase with dose and were similar to the control value, indicating that the trans-10, cis-12-18:2 found in milk of these cows originated from the rumen (Griinari and Bauman, 1999; Corl et al., 2002; Piperova et al., 2002). These 
Table 5. Concentration of fatty acids in milk of lactating cows fed diets supplemented with Ca salts of trans fatty acids (tFA) or conjugated linoleic acids (CLA). ${ }^{1}$

\begin{tabular}{|c|c|c|c|c|c|c|c|c|c|c|}
\hline & \multirow[b]{3}{*}{ Control } & \multirow{2}{*}{\multicolumn{3}{|c|}{ Ca-tFA }} & \multirow{3}{*}{$\frac{\text { Ca-CLA }}{100 \mathrm{~g}}$} & \multirow[b]{3}{*}{ SEM } & \multicolumn{4}{|c|}{ Contrast } \\
\hline & & & & & & & & & CLA vs. & CLA \\
\hline & & $100 \mathrm{~g}$ & $200 \mathrm{~g}$ & $400 \mathrm{~g}$ & & & $\mathrm{~L}^{2}$ & $\mathrm{Q}^{2}$ & control & $\mathrm{tFA}$ \\
\hline & & & & & $(\mathrm{g} / 100 \mathrm{~g}$ & AME) & & & & \\
\hline $14: 0$ & 11.3 & 10.6 & 10.5 & 10.2 & 10.3 & 0.37 & 0.08 & 0.24 & 0.64 & 0.18 \\
\hline $14: 1$ & 1.35 & 1.19 & 1.10 & 1.19 & 1.03 & 0.06 & 0.53 & 0.02 & 0.19 & 0.16 \\
\hline $15: 0$ & 0.27 & 0.43 & 0.29 & 0.29 & 0.23 & 0.04 & 0.20 & 0.10 & 0.40 & 0.24 \\
\hline $16: 0$ & 36.4 & 35.9 & 33.2 & 32.2 & 31.6 & 0.40 & 0.02 & 0.37 & 0.03 & 0.16 \\
\hline $16: 1 \mathrm{cis}$ & 2.08 & 1.70 & 1.84 & 1.75 & 1.34 & 0.20 & 0.21 & 0.23 & 0.05 & 0.07 \\
\hline $17: 0$ & 0.59 & 0.59 & 0.61 & 0.59 & 0.69 & 0.02 & 0.62 & 0.79 & 0.93 & 0.73 \\
\hline $17: 1$ & 0.24 & 0.18 & 0.22 & 0.20 & 0.27 & 0.02 & 0.27 & 0.87 & 0.31 & 0.69 \\
\hline $18: 0$ & 11.9 & 13.0 & 13.4 & 13.2 & 12.8 & 0.70 & 0.12 & 0.73 & 0.18 & 0.65 \\
\hline $18: 1 \mathrm{cis}$ & 26.4 & 26.7 & 28.4 & 27.6 & 28.4 & 1.10 & 0.14 & 0.11 & 0.43 & 0.43 \\
\hline 18:1trans & 2.88 & 3.99 & 4.31 & 5.37 & 3.02 & 0.20 & 0.01 & 0.37 & 0.73 & 0.01 \\
\hline $18: 2 n-6$ & 3.53 & 3.63 & 3.97 & 4.10 & 4.71 & 0.20 & 0.83 & 0.02 & 0.61 & 0.11 \\
\hline $18: 2 \mathrm{i}$ & 0.26 & 0.37 & 0.28 & 0.51 & 0.56 & 0.07 & 0.68 & 0.93 & 0.18 & 0.06 \\
\hline $18: 3 n-3$ & 0.47 & 0.46 & 0.52 & 0.53 & 0.55 & 0.02 & 0.50 & 0.11 & 0.47 & 0.15 \\
\hline CLA & 0.52 & 0.65 & 0.82 & 0.89 & 0.83 & 0.06 & 0.10 & 0.03 & 0.05 & 0.61 \\
\hline$\geq \mathrm{C} 20$ & 0.67 & 0.61 & 0.55 & 0.62 & 0.79 & 0.04 & 0.80 & 0.36 & 0.33 & 0.76 \\
\hline
\end{tabular}

${ }^{1}$ Values for fatty acids are least square means $(n=9)$. Some fatty acids $(\geq C: 14)$ which represent $<3 \%$ of the total fatty acid methyl esters (FAME) were not included. 18:2i = Nonconjugated dienes with one or two trans double bonds.

${ }^{2}$ Probability of a linear (L) and quadratic (Q) effect of dose level.

results were consistent with our finding that the CatFA supplement lacked any detectable trans-10, cis-1218:2 and strongly suggest that some components other than trans-10, cis-12-18:2 was involved in the MFD observed in cows fed the Ca-tFA supplement.
In addition to the trans-10, cis-12-18:2, dietary MFD has been associated with increased levels of tFA and, particularly, with an altered isomer pattern in which the trans-10-18:1 isomer was preferentially increased (Griinari et al., 1998; Newbold et al., 1998; Piperova,

Table 6. Yield of fatty acids in milk of lactating cows fed diets supplemented with Ca salts of trans fatty acids (tFA) or conjugated linoleic acids (CLA). ${ }^{1}$

\begin{tabular}{|c|c|c|c|c|c|c|c|c|c|c|}
\hline & \multirow[b]{3}{*}{ Control } & \multirow{2}{*}{\multicolumn{3}{|c|}{ Ca-tFA }} & \multirow{3}{*}{$\frac{\mathrm{Ca}-\mathrm{CLA}}{100 \mathrm{~g}}$} & \multirow[b]{3}{*}{ SEM } & \multicolumn{4}{|c|}{ Contrast } \\
\hline & & & & & & & & & CLA vs. & CLA \\
\hline & & $100 \mathrm{~g}$ & $200 \mathrm{~g}$ & $400 \mathrm{~g}$ & & & $\mathrm{~L}^{2}$ & $\mathrm{Q}^{2}$ & control & $\mathrm{tFA}$ \\
\hline $14: 0$ & 136.9 & 127.2 & 117.8 & 115.2 & 100.9 & 4.3 & 0.22 & 0.01 & 0.03 & 0.18 \\
\hline $14: 1$ & 16.6 & 14.5 & 13.1 & 12.9 & 9.2 & 1.3 & 0.01 & 0.02 & 0.05 & 0.06 \\
\hline $15: 0$ & 13.5 & 15.8 & 13.2 & 12.3 & 12.1 & 0.5 & 0.10 & 0.01 & 0.24 & 0.02 \\
\hline $16: 0$ & 436.3 & 398.9 & 366.1 & 350.5 & 321.2 & 11.1 & 0.63 & 0.01 & 0.34 & 0.06 \\
\hline $16: 1 \mathrm{cis}$ & 25.8 & 20.7 & 20.9 & 19.1 & 11.6 & 0.8 & 0.21 & 0.03 & 0.05 & 0.05 \\
\hline $17: 0$ & 7.3 & 7.1 & 6.9 & 6.3 & 5.2 & 0.4 & 0.10 & 0.02 & 0.08 & 0.17 \\
\hline $17: 1$ & 2.9 & 2.1 & 2.5 & 2.1 & 1.5 & 0.2 & 0.17 & 0.13 & 0.12 & 0.15 \\
\hline $18: 0$ & 145.5 & 156.8 & 153.2 & 139.1 & 112.4 & 5.1 & 0.02 & 0.03 & 0.05 & 0.19 \\
\hline 18:1cis & 323.7 & 345.1 & 344.7 & 286.5 & 258.3 & 19.0 & 0.04 & 0.11 & 0.43 & 0.08 \\
\hline 18:1trans & 36.1 & 45.5 & 48.3 & 56.9 & 31.2 & 3.1 & 0.01 & 0.03 & 0.07 & 0.01 \\
\hline $18: 2 n-6$ & 44.1 & 44.5 & 44.6 & 42.4 & 40.9 & 3.1 & 0.18 & 0.29 & 0.25 & 0.37 \\
\hline $18: 2 \mathrm{i}$ & 3.2 & 4.5 & 4.1 & 5.4 & 3.4 & 0.8 & 0.10 & 0.11 & 0.22 & 0.08 \\
\hline $18: 3 n-3$ & 5.9 & 5.6 & 6.0 & 5.6 & 4.3 & 0.5 & 0.06 & 0.21 & 0.07 & 0.66 \\
\hline CLA & 6.5 & 8.0 & 8.5 & 8.9 & 8.1 & 0.3 & 0.02 & 0.22 & 0.05 & 0.61 \\
\hline$\geq \mathrm{C} 20$ & 8.4 & 6.7 & 6.1 & 6.3 & 5.6 & 0.8 & 0.67 & 0.03 & 0.06 & 0.29 \\
\hline cis-mono FA & 371.2 & 381.3 & 379.0 & 319.6 & 281.6 & 13.2 & 0.04 & 0.06 & 0.05 & 0.07 \\
\hline PUFA & 53.1 & 54.6 & 53.9 & 53.3 & 48.6 & 2.3 & 0.15 & 0.25 & 0.15 & 0.93 \\
\hline SFA & 740.5 & 706.6 & 655.6 & 624.4 & 551.8 & 22.3 & 0.19 & 0.01 & 0.05 & 0.05 \\
\hline
\end{tabular}

${ }^{1}$ Values for fatty acids are least square means $(n=9)$. Some fatty acids $(\geq \mathrm{C}: 14)$ which represent $<3 \%$ of the total fatty acid methyl esters (FAME) were not included. 18:2i = Nonconjugated dienes with one or two trans double bonds. PUFA = Polyunsaturated FA; SFA = saturated FA.

${ }^{2}$ Probability of a linear (L) and quadratic (Q) effect of dose level. 
Table 7. Conjugated linoleic acid isomers in milk fat of lactating cows fed diets supplemented with Ca salts of trans fatty acids (tFA) or conjugated linoleic acids (CLA). ${ }^{1}$

\begin{tabular}{|c|c|c|c|c|c|c|c|c|c|c|}
\hline & \multirow[b]{3}{*}{ Control } & \multirow{2}{*}{\multicolumn{3}{|c|}{ Ca-tFA }} & \multirow{3}{*}{$\frac{\mathrm{Ca}-\mathrm{CLA}}{100 \mathrm{~g}}$} & \multirow[b]{3}{*}{ SEM } & \multicolumn{4}{|c|}{ Contrast } \\
\hline & & & & & & & & & CLA vs. & CLA vs. \\
\hline & & $100 \mathrm{~g}$ & $200 \mathrm{~g}$ & $400 \mathrm{~g}$ & & & $\mathrm{~L}^{2}$ & $\mathrm{Q}^{2}$ & control & $\mathrm{tFA}$ \\
\hline \multicolumn{11}{|l|}{ CLA isomers } \\
\hline $\mathrm{t}-7, \mathrm{c}-9$ & 11.25 & 12.83 & 14.19 & 14.43 & 9.10 & 0.52 & 0.01 & 0.39 & 0.01 & 0.01 \\
\hline$c-9, t-11$ & 76.82 & 75.49 & 75.83 & 76.06 & 67.94 & 0.97 & 0.01 & 0.01 & 0.01 & 0.01 \\
\hline $\mathrm{t}-10, \mathrm{c}-12$ & 1.32 & 1.12 & 0.98 & 0.81 & 3.48 & 0.16 & 0.01 & 0.01 & 0.01 & 0.01 \\
\hline $\mathrm{c}-11, \mathrm{t}-13$ & 0.46 & 0.61 & 0.55 & 0.55 & 3.40 & 0.11 & 0.01 & 0.01 & 0.01 & 0.01 \\
\hline trans/trans & 8.41 & 7.91 & 7.41 & 7.01 & 11.11 & 0.78 & 0.01 & 0.09 & 0.02 & 0.03 \\
\hline cis/cis & 1.64 & 1.66 & 1.02 & 1.06 & 4.50 & 0.29 & 0.06 & 0.64 & 0.02 & 0.02 \\
\hline $\mathrm{t}-7, \mathrm{c}-9$ & 0.82 & 1.07 & 1.29 & 1.30 & 0.66 & 0.09 & 0.05 & 0.20 & 0.25 & 0.05 \\
\hline $\mathrm{c}-9, \mathrm{t}-11$ & 4.99 & 5.95 & 6.76 & 6.80 & 5.50 & 0.34 & 0.03 & 0.22 & 0.05 & 0.05 \\
\hline $\mathrm{t}-10, \mathrm{c}-12$ & 0.09 & 0.09 & 0.08 & 0.07 & 0.28 & 0.03 & 0.07 & 0.11 & 0.01 & 0.01 \\
\hline $\mathrm{c}-11, \mathrm{t}-13$ & 0.03 & 0.05 & 0.05 & 0.05 & 0.19 & 0.01 & 0.01 & 0.01 & 0.01 & 0.01 \\
\hline trans/trans & 0.56 & 0.63 & 0.67 & 0.63 & 0.90 & 0.02 & 0.05 & 0.06 & 0.03 & 0.07 \\
\hline cis/cis & 0.11 & 0.13 & 0.09 & 0.10 & 0.36 & 0.02 & 0.03 & 0.05 & 0.05 & 0.05 \\
\hline
\end{tabular}

${ }^{1}$ Values for fatty acids are least square means $(n=9)$.

${ }^{2}$ Probability of a linear (L) or quadratic (Q) effect of Ca-tFA dose level.

et al., 2000; Peterson et al., 2003). By design, the CatFA supplement provided a high proportion of trans10-18:1 and elevated amounts of this isomer were incorporated into the milk fat of cows fed this supplement. It is tempting to ascribe the MFD observed in cows fed the Ca-tFA diets to the trans-10-18:1 isomer. Nevertheless, the Ca-tFA supplement contained several tFA iso- mers in relatively high proportions, and, in addition to the trans-10-18:1, the yields of trans-9, trans-11, and trans-12-18:1 were consistently increased in milk of cows fed increasing doses of the Ca-tFA supplement. It is unlikely that these tFA isomers are independently involved in MFD, as others have shown that trans-918:1 (Rindsig and Schultz, 1974; Newbold et al., 1998),

Table 8. Trans-18:1 fatty acid isomers in milk fat of lactating cows fed diets supplemented with Ca salts of trans fatty acids (tFA) and conjugated linoleic acids (CLA). ${ }^{1}$

\begin{tabular}{|c|c|c|c|c|c|c|c|c|c|c|}
\hline & \multirow[b]{3}{*}{ Control } & \multirow{2}{*}{\multicolumn{3}{|c|}{ Ca-tFA }} & \multirow{3}{*}{$\frac{\text { Ca-CLA }}{100 \mathrm{~g}}$} & \multirow[b]{3}{*}{ SEM } & \multicolumn{4}{|c|}{ Contrast } \\
\hline & & & & & & & & & CLA vs. & CLA \\
\hline & & $100 \mathrm{~g}$ & $200 \mathrm{~g}$ & $400 \mathrm{~g}$ & & & $\mathrm{~L}^{2}$ & $\mathrm{Q}^{2}$ & control & $\mathrm{tFA}$ \\
\hline \multicolumn{11}{|l|}{ Trans-18:1 isomers } \\
\hline $4+5$ & 0.92 & 1.57 & 1.19 & 1.36 & 1.04 & 0.13 & 0.17 & 0.15 & 0.50 & 0.03 \\
\hline $6+7+8$ & 2.88 & 3.57 & 5.15 & 3.63 & 2.45 & 0.59 & 0.33 & 0.03 & 0.63 & 0.02 \\
\hline 9 & 3.70 & 5.76 & 7.86 & 6.71 & 3.56 & 0.83 & 0.01 & 0.01 & 0.89 & 0.01 \\
\hline 10 & 13.10 & 14.49 & 18.20 & 19.20 & 12.65 & 0.74 & 0.01 & 0.04 & 0.65 & 0.01 \\
\hline 11 & 29.30 & 26.83 & 25.50 & 24.45 & 27.64 & 1.10 & 0.03 & 0.01 & 0.23 & 0.03 \\
\hline 12 & 12.69 & 12.22 & 12.76 & 12.25 & 13.29 & 0.50 & 0.88 & 0.72 & 0.41 & 0.11 \\
\hline $13+14$ & 22.68 & 20.95 & 19.00 & 20.73 & 24.08 & 0.36 & 0.01 & 0.01 & 0.02 & 0.01 \\
\hline 15 & 7.50 & 7.47 & 5.74 & 5.75 & 7.54 & 0.19 & 0.01 & 0.02 & 0.89 & 0.01 \\
\hline 16 & 7.14 & 7.14 & 5.60 & 5.52 & 7.75 & 0.37 & 0.03 & 0.77 & 0.26 & 0.02 \\
\hline $4+5$ & 0.33 & 0.71 & 0.57 & 0.77 & 0.32 & 0.09 & 0.02 & 0.10 & 0.06 & 0.05 \\
\hline $6+7+8$ & 1.04 & 1.62 & 2.49 & 2.07 & 0.70 & 0.34 & 0.05 & 0.96 & 0.11 & 0.01 \\
\hline 9 & 1.34 & 2.62 & 3.80 & 4.43 & 1.11 & 0.63 & 0.05 & 0.81 & 0.15 & 0.05 \\
\hline 10 & 4.74 & 6.59 & 8.79 & 10.92 & 3.95 & 0.62 & 0.01 & 0.35 & 0.17 & 0.01 \\
\hline 11 & 10.60 & 12.21 & 12.32 & 13.91 & 8.62 & 0.82 & 0.05 & 0.01 & 0.07 & 0.04 \\
\hline 12 & 4.58 & 5.56 & 6.16 & 6.97 & 4.15 & 0.47 & 0.02 & 0.42 & 0.21 & 0.05 \\
\hline $13+14$ & 8.19 & 9.53 & 9.18 & 11.80 & 7.51 & 0.70 & 0.03 & 0.07 & 0.16 & 0.06 \\
\hline 15 & 2.71 & 3.40 & 2.77 & 3.27 & 2.35 & 0.23 & 0.07 & 0.05 & 0.16 & 0.07 \\
\hline 16 & 2.58 & 3.25 & 2.68 & 3.37 & 2.42 & 0.22 & 0.08 & 0.06 & 0.07 & 0.06 \\
\hline
\end{tabular}

${ }^{1}$ Values for fatty acids are least square means $(n=9)$.

${ }^{2}$ Probability of a linear (L) or quadratic (Q) effect of Ca-tFA dose level. 
trans-11-18:1, and trans-12-18:1 (Newbold et al., 1998; Griinari et al., 2000) were ineffective in reducing milk fat in lactating cows.

Other tFA of interest were trans- $6+7+8-18: 1$ and trans-13+14-18:1, which were also present in the CatFA supplement and transferred in moderate amounts to the milk of cows fed this supplement. Increased concentrations of trans- $6+7+8-18: 1$ and trans-13+14-18:1 have been reported previously in milk of cows fed MFD diets (Griinari et al., 1998; Piperova et al., 2000, 2002; Precht et al., 2002; Peterson et al., 2003). However, the increase in trans-6+7+8-18:1 and trans-13+14-18:1 reported by others (Griinari et al., 1998; Loor and Herbein, 2003) was not always consistent with reduction in milk fat. Moreover, comparisons among the Ca-tFA treatments herein make it unlikely that these 2 groups of tFA are involved in MFD. Although the increase in trans-6+7+8-18: $1(\mathrm{~g} / \mathrm{d})$ over the control value was greatest for the 200-g Ca-tFA diet, this treatment did not result in the greatest decrease in milk fat yield. Conversely, the yield of trans-13+14-18:1 was lowest in cows fed the $200 \mathrm{~g}$ of Ca-tFA despite the moderate MFD observed with this dose. In other previous work, reduction in milk fat was not achieved in cows fed diets supplemented with 3 different fats (Kalscheur et al., 1997b), even though subsequent analysis of the milk fat revealed elevated levels of trans-6+7+8-18:1 (0.53, $0.79,0.82$, and $0.77 \mathrm{~g} / \mathrm{d})$ and trans-13+14-18:1 (9.76, $13.45,18.22$, and $22.8 \mathrm{~g} / \mathrm{d}$ ) respectively, for cows fed the control and the fat-supplemented diets (L. S. Piperova, 2001 , unpublished data). In view of the previous discussion, if a trans-18:1 isomer is involved in MFD, the trans-10-18:1 seems to be the most likely candidate.

In this study, sources of trans-10-18:1 in milk of cows fed the Ca-tFA diet included those arising from both rumen biohydrogenation of PUFA and Ca-tFA supplementation. Intake of trans-10-18:1 was $8.4,16.8$, and $33.4 \mathrm{~g} / \mathrm{d}$, respectively, with the $100-, 200-$, and $400-\mathrm{g}$ $\mathrm{Ca}-\mathrm{tFA}$ diets. If rumen biohydrogenation was the only source contributing to trans-10-18:1 in milk of the control cows, then the amount derived from the Ca-tFA was calculated to be $1.8,4.0$, and $6.2 \mathrm{~g} / \mathrm{d}$, respectively, for the 100-, 200-, and 400-g Ca-tFA diets. These increases in trans-10-18:1 were not as large as those observed previously during dietary induced MFD (Griinari et al., 1998; Piperova et al., 2000; Peterson et al., 2003 ) and corresponded to 21,23 , and $19 \%$ apparent transfer efficiencies with increasing doses of Ca-tFA. Partial hydrogenation of the Ca-tFA supplement might account for at least some of the reduced tFA in milk. Wu et al. (1991) showed that protection of unsaturated fatty acids from rumen biohydrogenation is incomplete and that $57 \%$ of dietary unsaturated fatty acids, fed as Ca salts, were hydrogenated by rumen microorganisms.
If we assume a biohydrogenation value of $57 \%$ for trans10-18:1, as Ca salt, amounts of this isomer available for transfer to milk would have been 3.8, 7.7, and 15.4 $\mathrm{g} / \mathrm{d}$, respectively, for cows fed the 100-, 200-, and 400g Ca-tFA diets. Thus, the increased yields of trans-1018:1 in milk would reflect transfer efficiencies from 40 to $52 \%$. These values are in general agreement with transfer efficiencies calculated for trans-10-18:1 from data comparing duodenal contents and milk fat in cows fed a MFD diet (Piperova et al., 2002).

The apparent transfer efficiency of trans-10, cis-1218:2 in this study (5\%) was somewhat higher than the 2.4 to $4.4 \%$ and $3.4 \%$ reported by Giesy et al. (2002) and Perfield II et al. (2002), respectively, for this isomer in milk of cows fed greater doses of rumen-protected CLA. The amount of trans-10, cis-12-18:2 in milk of the cows fed Ca-CLA $(0.28 \mathrm{~g} / \mathrm{d})$ was similar to the $0.30 \mathrm{~g} / \mathrm{d}$ observed in the study by Perfield II et al. (2002), resulting in a $23 \%$ decrease in milk fat yield in both studies. The apparent transfer efficiency of trans-10, cis-1218:2 from Ca-CLA supplements was lower compared with that observed (10 to 21\%) for this isomer during abomasal infusion of CLA supplements (Chouinard et al., 1999a, b). Nevertheless, the degree of milk fat reduction reported herein (23\%) and by Perfield II et al. (2002) was almost identical (24\%) to the MFD achieved in response to higher levels of trans-10, cis-12-18:2 (0.86 $\mathrm{g} / \mathrm{d}$ ) in milk provided by abomasal infusion of pure trans-10, cis-12 CLA (Baumgard et al., 2001). Thus, the MFD caused by the Ca-CLA diet was greater than expected based on the concentration of trans-10, cis-1218:2 in milk.

Discrepancies between concentrations of trans-10, cis-12-18:2 in milk and degree of milk fat reduction have been observed previously (Loor et al., 2002; Peterson et al., 2003) during dietary-induced MFD, suggesting that other substances may also be involved. In this experiment, the cis-9, trans-11-18:2; the cis-11, trans-13-18:2; the trans, trans and the cis, cis CLA isomers were also increased in milk by the Ca-CLA supplement. However, it has been demonstrated that abomasal infusion of $\mathrm{cis}$ 9, trans-11-18:2 (Baumgard et al., 2000) or trans-8, cis10 and cis-11, trans-13-18:2 (Perfield II et al., 2004) had no effect on milk fat synthesis, and Loor and Herbein (2003) did not observe MFD in feeding experiments in which the trans, trans and the cis, cis CLA isomers in milk were elevated. Perhaps, as Bauman and Griinari (2001, 2003) have suggested, other unidentified intermediates, produced in the rumen, may also be involved in MFD. Further research is required to investigate these discrepancies.

In this study, milk concentrations and yield of CLA were not different among cows fed the Ca-supplemented diets; however, changes in the CLA isomer pro- 
file were observed. It has been reported that formation of CLA in the rumen cannot account for the concentrations of CLA in milk (Piperova et al., 2002) and that $\triangle^{9}$-desaturation of ruminally derived trans-18:1 precursors is the primary source of cis-9 containing CLA in milk (Griinari et al., 2000; Corl et al., 2001, 2002). The increase in yield of cis-9 containing CLA observed in milk of cows fed Ca-tFA diets was in agreement with these findings. Compared with the control, milk secretion of trans-11-18:1 was increased by 15,16 , and $31 \%$, respectively, with the Ca-tFA diets and resulted in a 19\% (100 g Ca-tFA), 35\% (200 g Ca-tFA), and 36\% (400 g Ca-tFA) increase milk yield of cis-9, trans-11-18:2. Griinari et al. (2000) have shown that abomasal infusion of trans-11-18:1 in lactating cows resulted in a $31 \%$ increase in the yield of cis-9, trans-11-18:2, accounting for $12 \%$ of the infused trans monoene. Availability of trans-7-18:1 in milk was not determined in this experiment; however, milk yield of trans-7, cis-9-18:2 was increased by 30,57 , and $58 \%$, respectively, with increasing doses of Ca-tFA, suggesting that a sufficient amount of trans-7-18:1 was delivered to the mammary gland to account for the increase.

The cis-9, trans-11-18:2 in milk of cows fed Ca-CLA originated from 3 sources: biohydrogenation of PUFA in the rumen, endogenous synthesis via $\triangle^{9}$-desaturation of trans-11-18:1, and the amount transferred from the supplement. Under normal rumen conditions, the portion of cis-9, trans-11-18:2 that escapes biohydrogenation is minor (Piperova et al., 2002; Corl et al., 2002). Thus, we assumed that all of the milk cis-9, trans-1118:2 CLA was derived from the supplement and from endogenous synthesis. Furthermore, the amount derived from endogenous synthesis can be estimated from the quantity of this isomer in control milk, if $\triangle^{9}$-desaturation was not appreciably altered by the Ca-CLA supplement. Indeed, this appeared to be the case when we examined the values for the trans-7, cis-9-18:2, an isomer not present in the Ca-CLA supplement and known to be almost exclusively produced via $\triangle^{9}$-desaturation of trans-7-18:1 (Piperova et al., 2002; Corl et al., 2002). Because yields of trans-7, cis-9-18:2 and trans-6+7+8-18:1 in milk of cows fed Ca-CLA were not significantly different from the control values, we believe that $\triangle^{9}$-desaturation in the mammary gland was not altered by the Ca-CLA supplementation. This is consistent with data reported by Giesy et al. (2002) and Perfield II et al. (2002), showing that ratios of fatty acids representing product/substrate for $\triangle^{9}$-desaturase were not affected in milk of cows fed doses of Ca salts of CLA higher than those used in the present study. Hence, the apparent transfer efficiency of cis-9, trans11-18:2 from the supplement to milk (11\%) was calculated assuming that the difference in cis-9, trans-11-
18:2, compared with the control, was derived from the Ca-CLA supplement. A similar transfer efficiency (9 to 10\%) was reported for cis-9, trans-11-18:2 by Giesy et al. (2002) in lactating cows fed increasing doses of CaCLA-60. These transfer efficiencies were lower than the $22.5 \%$ observed for this isomer during abomasal infusion of a mixture of CLA isomers (Chouinard et al., 1999a). As suggested by Giesy et al. (2002), site of supplementation may be an important factor in the efficiency of CLA transfer into milk.

\section{CONCLUSIONS}

We have shown that dietary Ca-tFA supplementation can reduce milk fat content and yield; however, the MFD was less pronounced, compared with Ca-CLA supplementation. The concentration and yield of cis-9 containing CLA were highest in milk of cows fed the CatFA supplement, which provided the trans-7 and trans11-18:1 precursors for the endogenous synthesis of CLA in the mammary gland. The decrease in milk fat in cows fed Ca-CLA was associated with the greater level of trans-10, cis-12-18:2 in milk. In contrast, concentrations of trans-10, cis-12-18:2 were not altered by supplementation with Ca-tFA, whereas the levels of trans18:1, including the trans-10 isomer, were elevated in milk of cows fed the tFA supplements. These results provide evidence that an increase in trans-10, cis-1218:2 is not required for MFD and suggest that other components, including the trans-10-18:1, could also be involved.

\section{ACKNOWLEDGMENTS}

The authors thank Bioproducts, Inc. for providing the Ca supplements and the financial support for this study. The assistance of Emiko Yoshizumi with the milk fat analysis is greatly appreciated.

\section{REFERENCES}

Association of Official Analytical Chemists. 1990. Official Methods of Analysis. 15th ed. AOAC, Arlington, VA.

Bauman, D. E., and J. M. Griinari. 2001. Regulation and nutritional manipulation of milk fat: Low-fat milk syndrome. Livest. Prod. Sci. 70:15-29.

Bauman, D. E., and J. M. Griinari. 2003. Nutritional regulation of milk fat synthesis. Ann. Rev. Nutr. 23:203-227.

Baumgard, L. H., B. A. Corl, D. A. Dwyer, A. Saebo, and D. E. Bauman. 2000. Identification of the conjugated linoleic acid isomer that inhibits milk fat synthesis. Am. J. Physiol. 278:R179-R184.

Baumgard, L. H., J. K. Sangster, and D. E. Bauman. 2001. Milk fat synthesis in dairy cows is progressively reduced by increasing supplemental amounts of trans-10, cis-12 conjugated linoleic acid (CLA). J. Nutr. 131:1764-1769.

Bernal-Santos, G., J. W. Perfield, II, D. M. Barbano, D. E. Bauman, and T. R. Overton. 2003. Production responses of dairy cows to dietary supplementation with conjugated linoleic acid (CLA) dur- 
ing the transition period and early lactation. J. Dairy Sci. 86:3218-3228.

Chouinard, P. Y., L. Corneau, D. M. Barbano, L. E. Metzger, and D. E. Bauman. 1999a. Conjugated linoleic acids alter milk fat composition and inhibit milk fat secretion in dairy cows. J. Nutr. 129:1579-1584.

Chouinard, P. Y., L. Corneau, A. Saebo, and D. E. Bauman. 1999b. Milk yield and composition during abomasal infusion of conjugated linoleic acids in dairy cows. J. Dairy Sci. 82:2737-2745.

Corl, B. A., L. H. Baumgard, D. A. Dwyer, J. M. Griinari, B. S. Phillips, and D. E. Bauman. 2001. The role of $\triangle^{9}$-desaturase in the production of cis-9, trans-11 CLA. J. Nutr. Biochem. 12:622-630.

Corl, B. A., L. H. Baumgard, J. M. Griinari, P. Delmonte, K. M. Morehouse, M. P. Yurawecz, and D. E. Bauman. 2002. trans7, cis-9 CLA is synthesized endogenously by $\triangle^{9}$-desaturase in lactating cows. Lipids 37:681-688.

Eulitz, K., M. P. Yurawecz, N. Sehat, J. Fritsche, J. A. G. Roach, M. M. Mossoba, J. K. G. Kramer, R. O. Adlof, and Y. Ku. 1999. Preparation, separation, and confirmation of the eight geometrical cis/trans conjugated linoleic acid isomers 8,10-through 11,1318:2. Lipids 34:873-877.

Gaynor, P. J., R. A. Erdman, B. B. Teter, J. Sampugna, A. V. Capuco, D. R. Waldo, and M. Hamosh. 1994. Milk fat yield and composition during abomasal infusion of cis and trans octadecenoates in Holstein cows. J. Dairy Sci. 7:157-165.

Giesy, J. G., M. A. McGuire, B. Shafii, and T. W. Hanson. 2002. Effect of dose of calcium salts of conjugated linoleic acid (CLA) on percentage and fatty acid content of milk in midlactation Holstein cows. J. Dairy Sci. 85:2023-2029.

Griinari, J. M., and D. E. Bauman. 1999. Biosynthesis of conjugated linoleic acid and its incorporation into meat and milk in ruminants. Pages 180-200 in Advances in Conjugated Linoleic Acid Research. Vol. 1. M. P. Yurawecz, M. M. Mossoba, J. K. G. Kramer, M. Pariza, and G. J. Nelson, ed. AOCS Press, Champaign, IL.

Griinari, J. M., B. A. Corl, S. H. Lacy, P. Y. Chouinard, K. V. V. Nurmela, and D. E. Bauman. 2000. Conjugated linoleic acid is synthesized endogenously in lactating dairy cows by $\triangle^{9}$-desaturase. J. Nutr. 130:2285-2291.

Griinari, J. M., D. A. Dwyer, M. A. McGuire, D. E. Bauman, D. L. Palmquist, and K. V. V. Nurmela. 1998. Trans-octadecenoic acids and milk fat depression. J. Dairy Sci. 81:1251-1261.

Griinari, J. M., K. V. V. Nurmela, D. A. Dwyer, D. M. Barbano, and D. E. Bauman. 1999. Variation of milk fat concentration of conjugated linoleic acid and milk fat percentage is associated with a change in ruminal biohydrogenation. J. Anim. Sci. 77(Suppl.1):117-118. (Abstr.)

Kalscheur, K. F., B. B. Teter, L. S. Piperova, and R. A. Erdman. 1997a. Effect of dietary forage concentration and buffer addition on duodenal flow of trans-C18:1 fatty acids and milk fat production in dairy cows. J. Dairy Sci. 80:2104-2114.

Kalscheur, K. F., B. B. Teter, L. S. Piperova, and R. A. Erdman. 1997b. Effect of fat source on duodenal flow of trans-18:1 fatty acids and milk fat production in dairy cows. J. Dairy Sci. 80:2115-2126.

Katz, I., and M. Keeney. 1966. Characterization of the octadecenoic acids in rumen digesta and rumen bacteria. J. Dairy Sci. 49:962-966.

Loor, J. J., A. Ferlay, A. Ollier, M. Doreau, and Y. Chilliard. 2002. Conjugated linoleic acids (CLA), trans fatty acids, and lipid content in milk from Holstein cows fed a high- or low-fiber diet with two levels of linseed oil. J. Dairy Sci. 85(Suppl. 1):1188. (Abstr.)
Loor, J. J., and J. H. Herbein. 2001. Alterations in blood plasma and milk fatty acid profiles of lactating Holstein cows in response to ruminal infusion of a conjugated linoleic acid mixture. Anim. Res. 50:463-476.

Loor, J. J., and J. H. Herbein. 2003. Dietary canola or soybean oil with two levels of conjugated linoleic acids (CLA) alter profiles of 18:1 and 18:2 isomers in blood plasma and milk fat from dairy cows. Anim. Feed Sci. Technol. 103:63-83.

Newbold, J. R., K. L. Robertshaw, and H. W. Morris. 1998. Association between concentrations of fat and intermediates of ruminal biohydrogenation in milk of dairy cows. Proc. Br. Soc. Anim. Sci.:224. (Abstr.)

Parodi, P. W. 1977. Conjugated octadecadienoic acids in milk fat. J. Dairy Sci. 60:1550-1553.

Perfield, II, J. W., G. Bernal-Santos, T. R. Overton, and D. E. Bauman. 2002. Effects of dietary supplementation of rumen-protected conjugated linoleic acid in dairy cows during established lactation. J. Dairy Sci. 85:2609-2617.

Perfield, II, J. W., A. Saebo, and D. E. Bauman. 2004. Use of conjugated linoleic acid (CLA) enrichments to examine the effects of trans-8, cis-10 CLA and cis-11, trans-13 CLA on milk fat synthesis. J. Dairy Sci. 87:1196-1202.

Peterson, D. G., E. A. Matitashvili, and D. E. Bauman. 2003. Dietinduced milk fat depression in dairy cows results in increased trans-10, cis-12 CLA in milk and coordinate suppression of mRNA abundance for mammary enzymes involved in milk fat synthesis. J. Nutr. 133:3098-3102.

Piperova, L. S., J. Sampugna, B. B. Teter, K. F. Kalscheur, M. P. Yurawecz, Y. Ku, K. M. Morehouse, and R. E. Erdman. 2002. Duodenal and milk trans octadecenoic acid and conjugated linoleic acid (CLA) isomers indicate that postabsorptive synthesis is the predominant source of cis-9 containing CLA in lactating cows. J. Nutr. 132:1235-1241.

Piperova, L. S., B. B. Teter, I. Bruckental, J. Sampugna, S. E. Mills, M. P. Yurawecz, J. Fritsche, K. Ku, and R. A. Erdman. 2000. Mammary lipogenic enzyme activity, trans fatty acids and conjugated linoleic acids are altered in lactating cows fed a milk fatdepressing diet. J. Nutr. 130:2568-2574.

Precht, D., H. Hagemeister, W. Kanitz, and J. Voigt. 2002. Transfatty acids and conjugated linoleic acids in milk fat from dairy cows fed a rumen-protected linoleic acid rich diet. Kieler Milchwirtschaftliche Forschungsberichte 54:225-242.

Rindsig, R. B., and L. H. Schultz. 1974. Effect of abomasal infusion of safflower oil or elaidic acid on blood lipids and milk fat in dairy cows. J. Dairy Sci. 57:1459-1466.

Romo, G. A., D. P. Casper, R. A. Erdman, and B. B. Teter. 1996. Abomasal infusion of cis or trans fatty acid isomers and energy metabolism of lactating dairy cows. J. Dairy Sci. 79:2005-2015.

Sampugna, J., L. A. Pallansch, M. G. Enig, and M. Keeney. 1982. Rapid analysis of trans fatty acids on SP-2340 glass capillary columns. J. Chromatogr. 249:245-255.

SAS User's Guide: Statistics, Version 6.12 edition. 1998. SAS Inst., Inc., Cary, NC.

Sehat, N., M. P. Yurawecz, J. A. G. Roach, M. M. Mossoba, J. K. G. Kramer, and Y. Ku. 1998. Silver ion high performance liquid chromatographic separation and identification of conjugated linoleic acid isomers. Lipids 33:217-221.

Wu, Z., O. A. Ohajuruka, and D. L. Palmquist. 1991. Ruminal synthesis, biohydrogenation, and digestability of fatty acids by dairy cows. J. Dairy Sci. 74:3025-3034.

Wu, Z., and D. L. Palmquist. 1991. Synthesis and biohydrogenation of fatty acids by ruminal microorganisms in vitro. J. Dairy Sci. 74:3035-3046. 